\title{
Phosphate Control: The Next Frontier in Dialysis Cardiovascular Mortality
}

\author{
Peter A. McCullough ${ }^{a, b}, c$ \\ ${ }^{a}$ Baylor University Medical Center, Dallas, TX, USA; ${ }^{b}$ Department of Internal Medicine, Texas A \& M College of \\ Medicine, Baylor Heart and Vascular Institute, Dallas, TX, USA; 'Baylor Jack and Jane Hamilton Heart and Vascular \\ Hospital, Dallas, TX, USA
}

\section{Keywords}

Chronic kidney disease - Cardiovascular vascular mortality . Hyperphosphatemia - Fibroblast growth factor 23 .

Parathyroid hormone - Vascular calcification - Congestive heart failure · Left ventricular hypertrophy

\begin{abstract}
Background: Cardiovascular disease (CVD) is a major cause of death in patients with chronic kidney disease (CKD) on dialysis. Mortality rates are still unacceptably high even though they have fallen in the past 2 decades. Hyperphosphatemia (elevated serum phosphate levels) is seen in almost all patients with advanced CKD and is by far the largest remaining modifiable contributor to CKD mortality. Summary: Phosphate retention drives multiple physiological mechanisms linked to increased risk of CVD. Fibroblast growth factor 23 and parathyroid hormone (PTH) levels, both of which have been suggested to have direct pathogenic CV effects, increase in response to phosphate retention. Phosphate, calcium, and PTH levels are linked in a progressively worsening cycle. Maladaptive upregulation of phosphate absorption is also likely to occur further exacerbating hyperphosphatemia. Even higher phosphate levels within the normal range may be a risk factor for vascular calcification and, thus, CV morbidity and mortality. A greater degree of phosphate control is
\end{abstract}

karger@karger.com www.karger.com/crm

Karger $\stackrel{\text { ' }}{5}$
(C) 2021 The Author(s)

Published by S. Karger AG, Basel

This is an Open Access article licensed under the Creative Common Attribution-NonCommercial-4.0 International License (CC BY-NC) (http://www.karger.com/Services/OpenAccessLicense), applicable to the online version of the article only. Usage and distribution for commercial purposes requires written permission. important to reduce the risk of CV morbidity and mortality. Improved phosphate control and regular monitoring of phosphate levels are guideline-recommended, established clinical practices. There are several challenges with the current phosphate management approaches in patients with CKD on dialysis. Dietary restriction of phosphate and thrice-weekly dialysis alone are insufficient/unreliable to reduce phosphate to $<5.5 \mathrm{mg} / \mathrm{dL}$. Even with the addition of phosphate binders, the only pharmacological treatment currently indicated for hyperphosphatemia, the majority of patients are unable to achieve and maintain phosphate levels $<5.5 \mathrm{mg} / \mathrm{dL}$ (or more normal levels) [PhosLo ${ }^{\circledR}$ gelcaps (calcium acetate): $667 \mathrm{mg}$ (prescribing information), 2011, VELPHORO ${ }^{\circledR}$ : (Sucroferric oxyhydroxide) (prescribing information), 2013, FOSRENAL ${ }^{\circledR}$ : (Lanthanum carbonate) (prescribing information), 2016, AURYXIA ${ }^{\circledR}$ : (Ferric citrate) tablets (prescribing information), 2017, RENVELA ${ }^{\circledR}$ : (Sevelamer carbonate) (prescribing information), 2020, RealWorld dynamix. Dialysis US: Spherix Global Insights, 2019]. Phosphate binders do not target the primary pathway of phosphate absorption (paracellular), have limited binding capacity, and bind nonspecifically [PhosLo ${ }^{\circledR}$ gelcaps (calcium acetate): $667 \mathrm{mg}$ (prescribing information). 2013, VELPHORO ${ }^{\circledR}$ : (Sucroferric oxyhydroxide) (prescribing information), 2013, FOSRENAL ${ }^{\circledR}$ : (Lanthanum carbonate) (prescribing information), 2016, AURYXIA ${ }^{\circledR}$ : (Ferric citrate) tablets (prescribing information), 2017, RENVELA ${ }^{\circledR}$ : (Sevelam- 
er carbonate) (prescribing information) 2020]. Key Messages: Despite current phosphate management strategies, most patients on dialysis are unable to consistently achieve target phosphate levels, indicating a need for therapeutic innovations [RealWorld dynamix. Dialysis US: Spherix Global Insights, 2019]. Given a growing evidence base that the dominant mechanism of phosphate absorption is the intestinal paracellular pathway, new therapies are investigating ways to reduce phosphate levels by blocking absorption through the paracellular pathway.

(C) 2021 The Author(s)

Published by S. Karger AG, Basel

\section{Introduction}

Cardiovascular disease (CVD) is a major cause of death in patients with CKD on dialysis. Mortality rates in patients on dialysis have fallen in the past 2 decades [1]. Changes that may have contributed to this include a decrease in catheter placements and a concurrent rise in fistula placements, an emphasis on lower target hemoglobin levels, and more intensive nutritional support for patients [1-3]. However, mortality and hospitalization data showed little change after 2014, and current rates are still unacceptably high $[4,5]$. In the USA, the all-cause adjusted mortality rate in patients with end-stage renal disease (ESRD) was 140 deaths per 1,000 patients-years in 2016 [5]. Patients with ESRD on dialysis have an even higher mortality rate ( 160 deaths per 1,000 patientyears) [4]. These rates are higher than those of some cancers; the unadjusted probability of 5-year survival is $~ 50 \%$ in patients with dialysis compared to $83 \%$ for prostate cancer, $56 \%$ for colorectal cancer, and $82 \%$ for breast cancer [6]. Novel approaches may be necessary to further improve clinical outcomes and quality of life in patients on dialysis [7].

CVD accounted for $\sim 62 \%$ of deaths among patients with chronic kidney disease (CKD) on dialysis in 2017 [4]. The majority of patients with CKD die from CVD, not kidney dysfunction, and mortality due to CVD in patients on dialysis is approximately 20 times higher than in a general population [8]. Traditional risk factors for $\mathrm{CV}$ mortality (e.g., hypertension, diabetes, diet, and lifestyle) alone do not explain the high CV morbidity and mortality in patients with CKD [9], and the established treatment strategies for these risk factors have not seen significant recent advancements. CKD-mineral bone disorder (CKD-MBD) is a common complication in patients with CKD known to be associated with $\mathrm{CV}$ morbidity and mortality [10]. CKD-MBD is characterized by laboratory abnormalities, bone abnormalities, and vascular calcification, which directly lead to CVD, fractures, and mortality [10]. The initiating and driving force of the mineral and endocrine disruptions that comprise CKD-MBD is phosphate retention [10]. Because CKD-MBD is pathobiologically related to myocardial disease, atherosclerosis, and vascular stiffness, it could be viewed as a treatment target since these mechanisms collectively play a potentially large role in CV outcomes in ESRD. Potential $\mathrm{CKD}$-related therapeutic approaches that may reduce $\mathrm{CV}$ mortality include improved dialysis modalities, management of kidney disease-MBD, serum phosphate levels, and inflammation [11-14].

\section{Phosphate Retention Is a Significant Contributor to CVD}

As CKD progresses, renal function declines and patients experience phosphate retention [15-22]. Although compensatory increases in parathyroid hormone (PTH) and fibroblast growth factor 23 (FGF23) are initially sufficient to offset phosphate retention; these mechanisms are eventually overwhelmed [15-22]. Uncontrolled phosphate retention leads to elevated serum phosphate levels, or hyperphosphatemia, when the glomerular filtration rate falls to $<30 \mathrm{~mL} / \mathrm{min} / 1.73 \mathrm{~m}^{2}[23,24]$. This rate corresponds to CKD stages 4 and 5 [25].

Lack of phosphate control is a potential major modifiable risk factor for CV mortality in patients with CKD (Fig. 1) [26, 27]. Elevated phosphate levels are by far the largest remaining modifiable contributor to CKD mortality on a population attributable risk basis, 2-6 fold higher than other top risk factors such as hypercalcemia, hyperparathyroidism, low urea reduction ratio, and anemia ( $12 \%$ vs. $4,2,5$, and $6 \%$, respectively) [28]. Additionally, $\sim 70 \%$ of patients on dialysis have left ventricular hypertrophy, a known risk factor for CVD and mortality strongly associated with higher phosphate levels [8]. Elevated phosphate is also directly linked to hypertension, a major CVD risk factor that is seen in up to $90 \%$ of patients with CKD [8].

Phosphate retention drives multiple physiological mechanisms linked to an increased risk of CVD [29, 30]. Hyperphosphatemia may directly affect vascular health by increasing reactive oxygen species, causing oxidative damage and endothelial dysfunction [29]. Both phosphate and calcium contribute to the development of vascular calcification, but phosphate is the initiating factor [31]. High phosphate conditions also increase vascular 


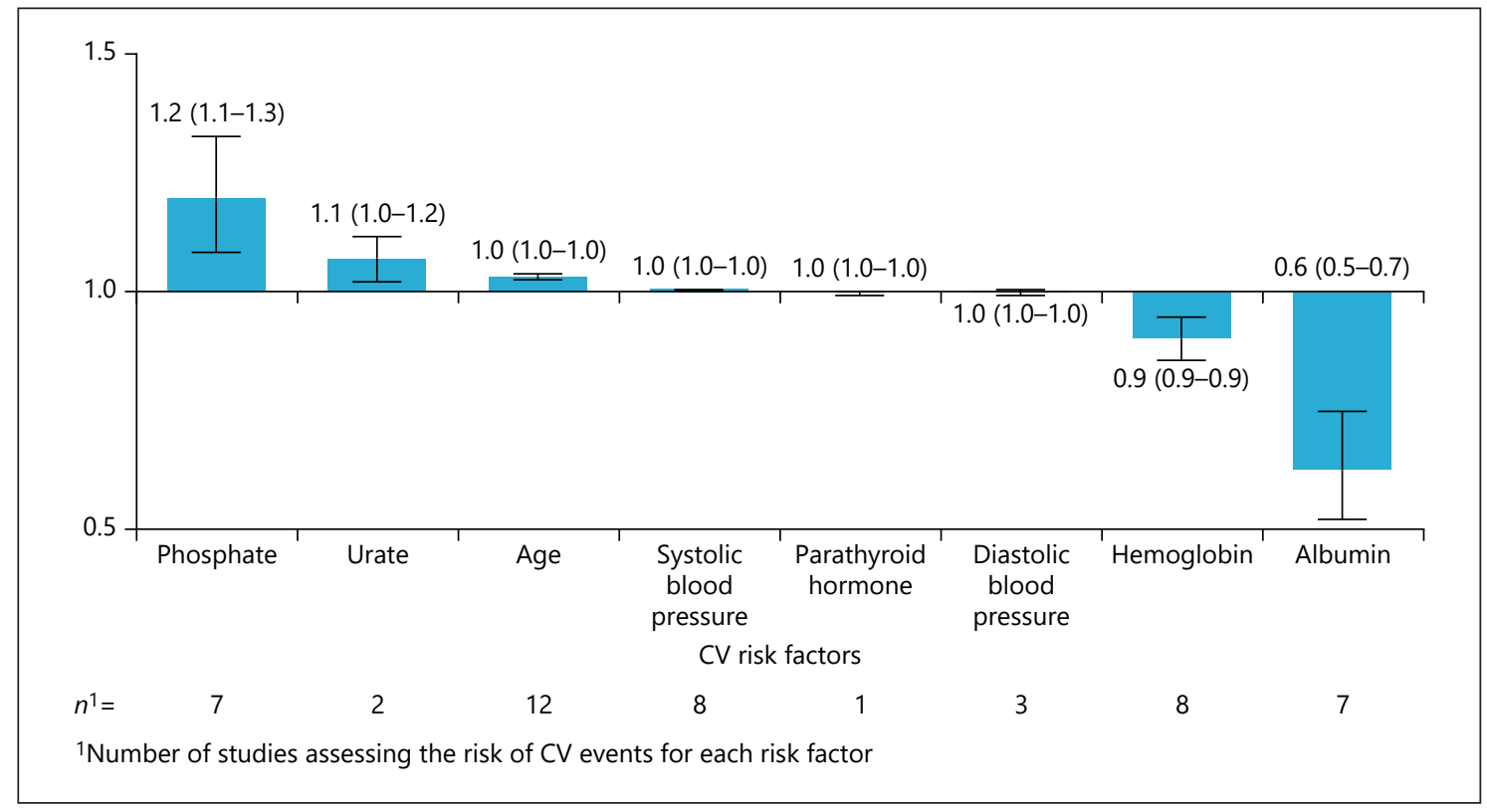

Fig. 1. Hazard ratio (95\% confidence interval) of CV events by CV risk factors. CV, cardiovascular; PTH, parathyroid hormone.

Fig. 2. Mechanism of elevated phosphate concentration causing $\mathrm{CV}$ risk. CV, cardiovascular.

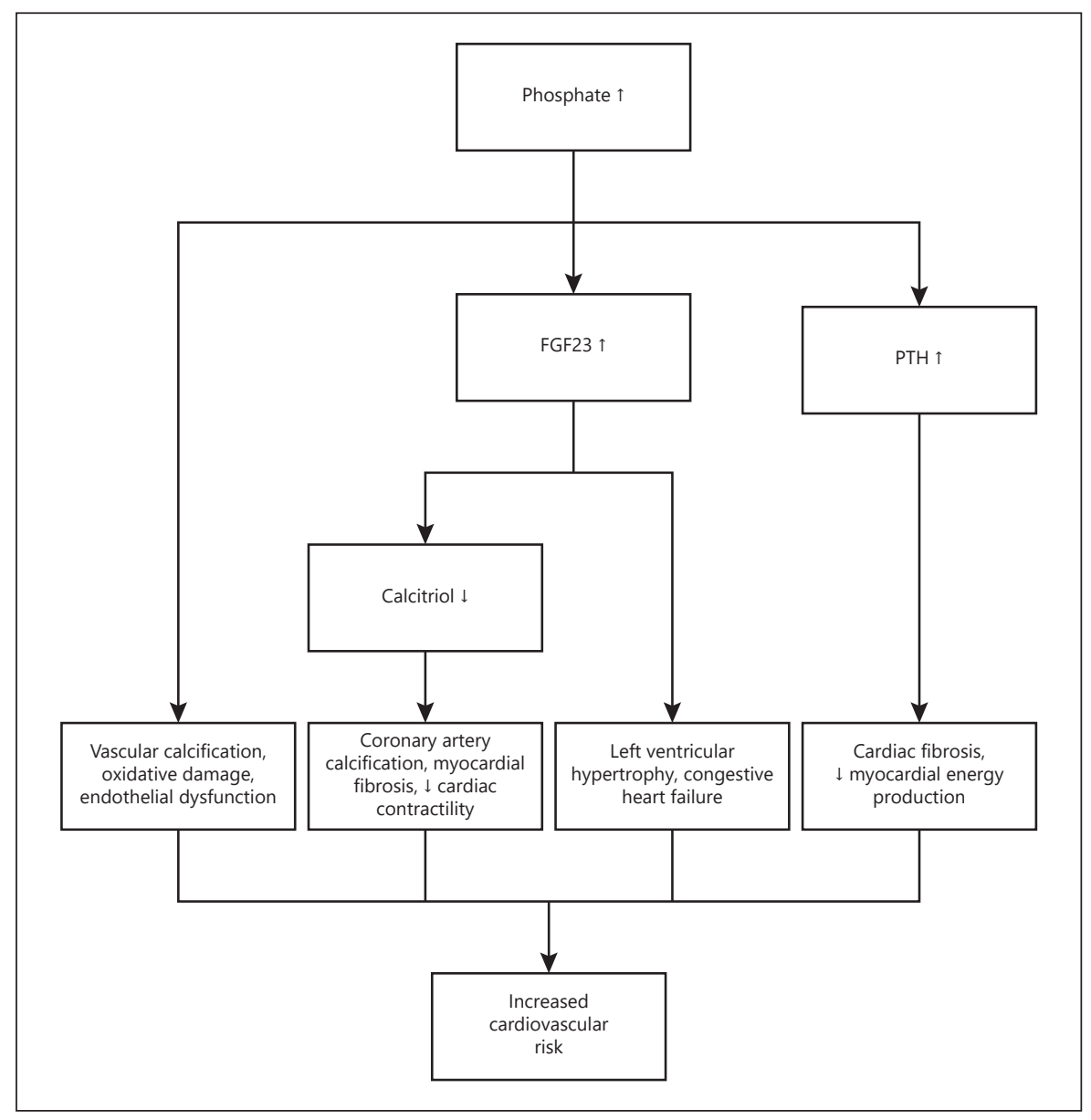

Phosphate Control: The Next Frontier in Dialysis Cardiovascular Mortality
Cardiorenal Med 2021;11:123-132 
Fig. 3. Illustration of phosphate absorption pathways.

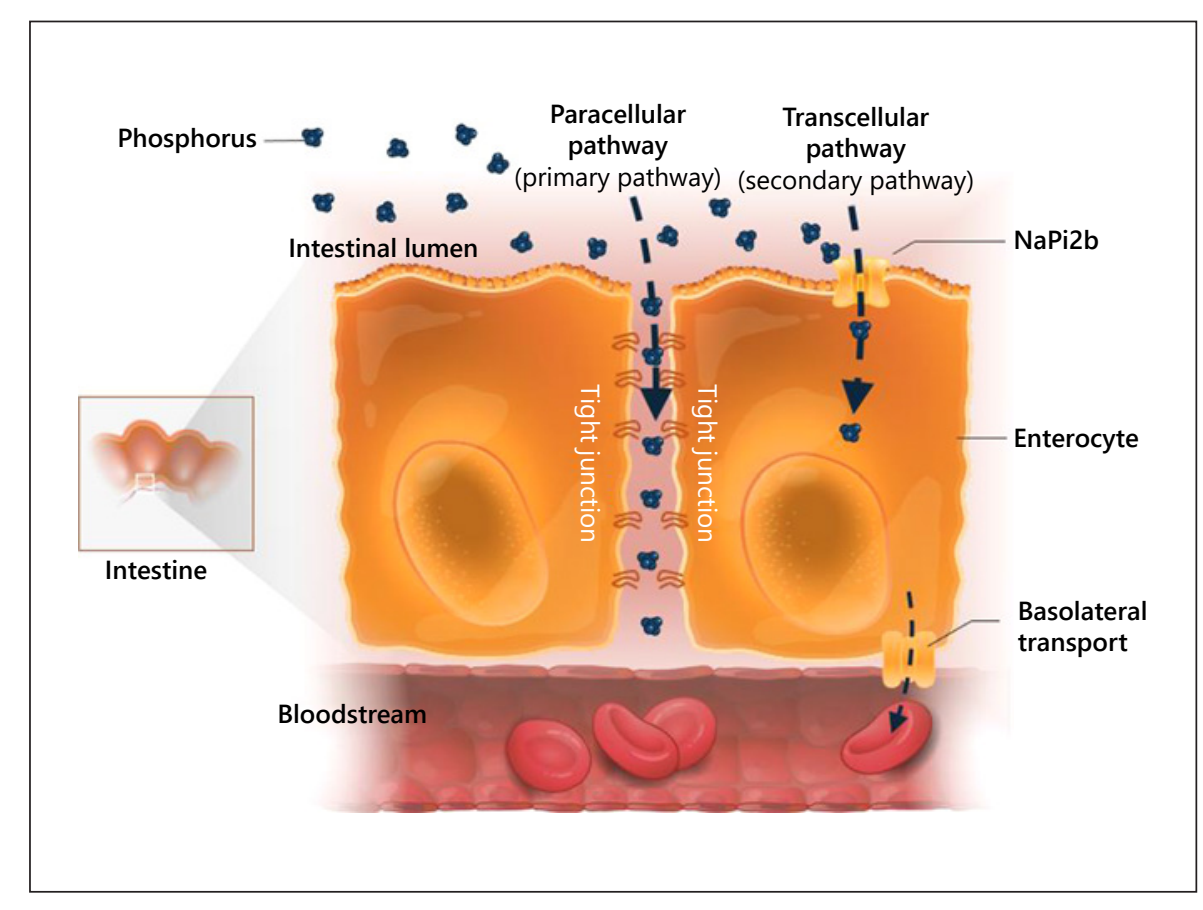

calcification by inducing changes in vascular smooth muscle cells [32]. Phosphate directly targets the PiT1 receptor on vascular smooth muscle cells, causing them to transform into osteoblast-like cells permanently $[33,34]$. Once this transformation occurs, these osteoblast-like cells begin to produce hydroxyapatite deposits normally found in the bone [35, 36]. Increased calcium-phosphorus product may accelerate this mineralization process after initiation [31]. This phosphate-induced calcification of vascular smooth muscle cells increases the risk of coronary artery events, procedural complications, and CV morbidity and mortality, as well as hypertension [37].

Phosphate retention triggers increases in fibroblast growth factor 23 and PTH levels, both of which have been suggested to have direct pathogenic CV effects [38-40]. Increased FGF23 levels directly promote left ventricular hypertrophy and congestive heart failure [38, 39]. Patients with CKD are likely to have experienced long periods of high FGF23 levels by the time they start dialysis; $36 \%$ of patients with CKD beginning dialysis already have heart failure [41]. The deleterious CV effects of elevated FGF23 may be exacerbated by common CKD comorbidities such as hypertension and diabetes [38, 42-44]. Increased PTH levels are associated with a pro-inflammatory effect, increased interleukin 6, impaired myocardial energy production, and cardiac fibrosis $[45,46]$. In- creased serum phosphate levels have also been associated with the inhibition of 1,25-dihydroxy vitamin $\mathrm{D}$ synthesis, which is associated with decreased cardiac contractility, coronary artery calcification, myocardial fibrosis, and pro-inflammatory effect [47-51].

Phosphate, $\mathrm{PTH}$, and calcium levels are linked in a regulatory cycle in which phosphate is the initiating and driving factor. Increasing phosphate levels trigger not only an increase in PTH but also a decrease in serum calcium [52]. When hypocalcemia develops, PTH levels increase to drive calcium and phosphate to travel out of bone reservoirs [10,11]. The subsequent increase in phosphate levels starts the cycle again $[10,11]$. Without effective phosphate control, this cycle will continue and progressively worsen [10] (Fig. 2).

Absorption of dietary phosphate via the dominant passive paracellular pathway and the active transcellular pathway is not downregulated in patients with CKD [53] (Fig. 3) In fact, a maladaptive upregulation of intestinal phosphate absorption in response to reduced phosphate in the gut due to dietary phosphate restriction and phosphate binding may also occur, further exacerbating phosphate retention [54]. This response may contribute to an explanation for the limited efficacy of dietary restriction and phosphate binders; neither of these phosphate management strategies targets phosphate absorption pathways and are therefore inherently limited [55-59]. 
Table 1. Multiple observational studies show an association between elevated serum phosphate and mortality in patients with CKD on dialysis [65-90]

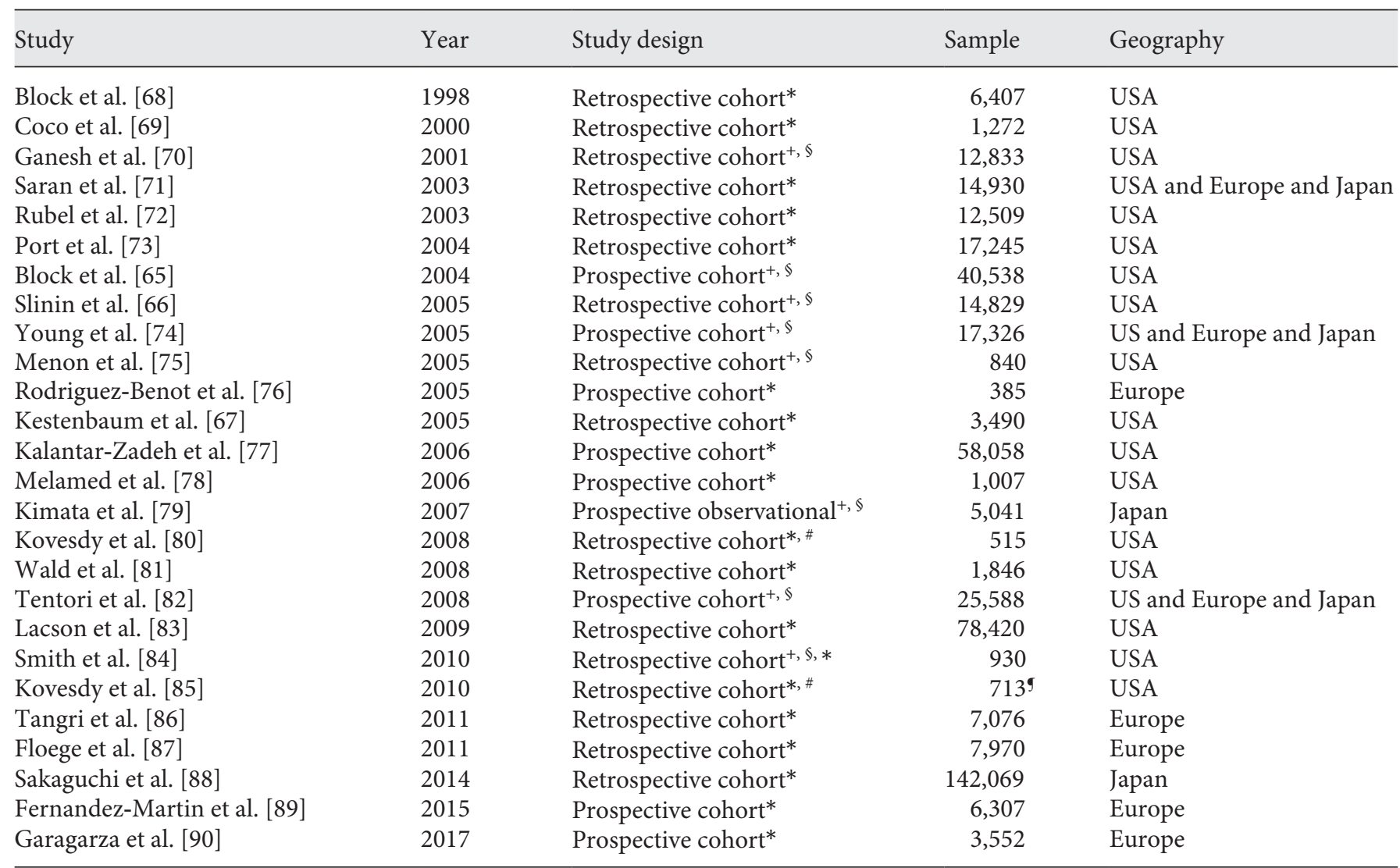

CKD, chronic kidney disease; CV, cardiovascular. * All-cause mortality. ${ }^{+} \mathrm{CV}$ mortality. ${ }^{\S}$ Nonfatal CV event. ${ }^{\#}$ Nondialysis-dependent moderate-severe CKD. 9 Nondialysis-dependent CKD.

The association between increased phosphate levels and CV morbidity/mortality is not limited to hyperphosphatemia or patients with CKD. Phosphate retention, even when phosphate levels are within the normal range, is known to increase the risk of death, CV events, and vascular calcification in both healthy adults and patients with CKD [30]. Phosphate levels of 3.9-4.7 mg/dL were associated with increased CV events in people with normal renal function and CKD stage 1 and 2 patients [60]. In people with normal renal function, the association between phosphate levels and CV risk is linear [60].

Although evidence on the association between phosphate and CV risk is observational, the volume of data that links elevated phosphate levels and increased CV morbidity and mortality in individuals with and without CKD is significant. This connection has been accepted by clinicians and researchers for decades $[7,8,11,26,60-64]$ (Table 1).

Phosphate Control: The Next Frontier in

Dialysis Cardiovascular Mortality

\section{Phosphate Control Is Associated with a Reduced Risk of CV Morbidity and Mortality}

Phosphate levels are an impactful modifiable risk factor for theoretically lowering CV morbidity and mortality in patients with CKD $[27,91]$. Abnormal phosphate levels have been shown to be an independent risk factor for $\mathrm{CV}$ morbidity and mortality in patients with CKD [60, 92-94], and there is a linear relationship between risk of CVD hospitalizations and mortality and increasing serum phosphate concentrations [65]. Patients with the worst phosphate control $(>7.5 \mathrm{mg} / \mathrm{dL})$ had a $25 \%$ greater risk of CV events than those with phosphate $<4.5 \mathrm{mg} / \mathrm{dL}$ [66]. Patients on dialysis with serum phosphate levels $>6.5 \mathrm{mg} / \mathrm{dL}$ were found to have $\sim 27 \%$ greater risk of mortality than those with levels between 2.4 and $6.5 \mathrm{mg} / \mathrm{dL}$ $[65,93]$. Serum phosphate levels over the reference range of $4.0-5.0 \mathrm{mg} / \mathrm{dL}$ resulted in up to $102 \%$ increased relative 


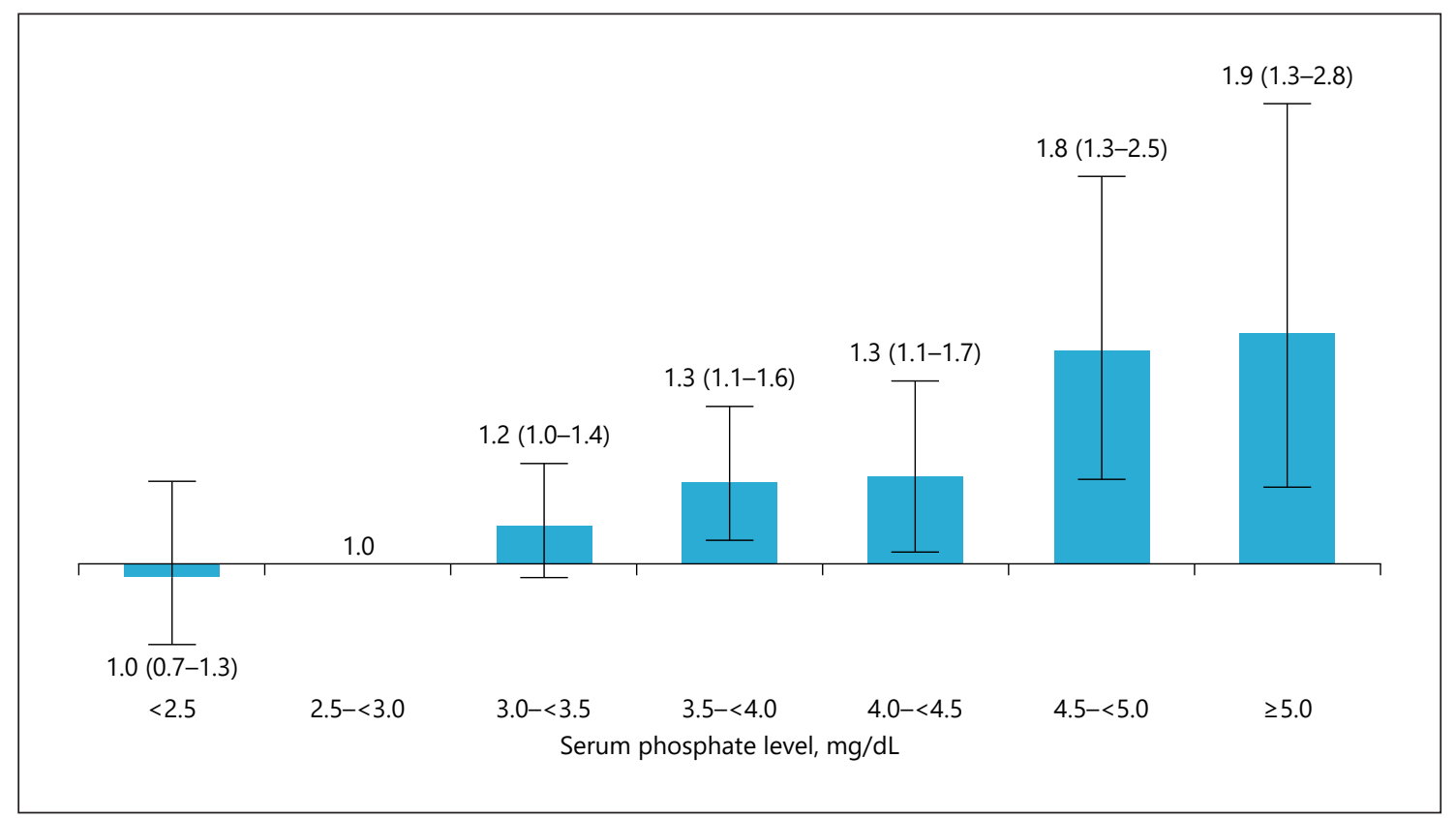

Fig. 4. Hazard ratio ( $95 \%$ confidence interval) for mortality by serum phosphate levels in patients with CKD.

risk of death (relative risk of 1.07, 1.25, 1.43, 1.67, and 2.02 for serum phosphorus 5.0-6.0, 6.0-7.0, 7.0-8.0, 8.0-9.0, and $\geq 9.0 \mathrm{mg} / \mathrm{dL}$, respectively) [65].

In addition to the degree of phosphate increase, time spent with elevated phosphate levels also increases CV mortality risk. A large multinational study of patients on dialysis found that the more time patients spent with phosphate $>4.5 \mathrm{mg} / \mathrm{dL}$ over a 6 -month period, the greater their risk of CV mortality [26].

Even in patients with CKD in early, pre-dialysis stage, an increase in phosphate within the normal range was predictive of CV morbidity and mortality. So, improved phosphate control and regular monitoring of phosphate levels are beneficial for all patients with CKD (Fig. 4) [67, 95]. Thus, reduction of phosphate to more normal levels is a guideline-recommended, established clinical practice $[10,96]$.

\section{Challenges of Current Phosphate Management in Patients with CKD}

Current phosphate management strategies are composed of dietary phosphate restriction, dialysis, and phosphate binders [97]. Dietary restriction of phosphate and dialysis are insufficient/unreliable alone to reduce phosphate to $<5.5 \mathrm{mg} / \mathrm{dL}$ [98]. Phosphate binders, which work by binding to dietary phosphate to create insoluble complexes that are then excreted, are the only pharmacological treatment currently indicated for hyperphosphatemia $[10,55-59]$. As a class, binders are insufficient to achieve and maintain phosphate levels $<5.5 \mathrm{mg} / \mathrm{dL}$ (or more normal levels) for the majority of patients on dialysis [99]. Binders do not target any phosphate absorption pathway, let alone the primary paracellular pathway, severely limiting their ability to impact absorption [55-59]. Nonspecific binding contributes to suboptimal efficacy and drugdrug interactions. A short duration of actions requires that binders be taken with each meal or snack. And a limited binding capacity per pill requires many large pills (pill requirements increase as phosphate intake increases) [100].

The insufficiency of current phosphate management strategies to consistently achieve and maintain target phosphate levels is well documented [99]. In the USA, an average of $40 \%$ of patients on dialysis had serum phosphate levels $>5.5 \mathrm{mg} / \mathrm{dL}$ in the most recent months [101]. Based on a chart audit, $42 \%$ of patients on dialysis treated with phosphate binders continue to have phosphate $>5.5$ $\mathrm{mg} / \mathrm{dL}$ in any given month and $77 \%$ are unable to consistently maintain phosphate levels $\leq 5.5 \mathrm{mg} / \mathrm{dL}$ over a 6 -month period [99]. Therapeutic innovations to reduce the negative clinical outcomes of poorly controlled phosphate levels are needed. 


\section{Phosphate Control Therapies Are Needed to Reduce the Risk of CV Morbidity and Mortality}

Phosphate binders act by "scavenging" dietary phosphate to prevent intestinal absorption and do not target or interact with phosphate absorption pathways [55-59]. Given the insufficiency of current phosphate management strategies to achieve and maintain phosphate concentrations $<5.5 \mathrm{mg} / \mathrm{dL}$ and the understanding that maladaptive hyperabsorption of phosphate limits the efficacy of low-phosphate diets and phosphate binders, there is a need for novel hyperphosphatemia therapies [54, 99]. Several novel therapies that target the active transcellular phosphate pathway have been developed. The sodiumdependent phosphate co-transporter type $2 \mathrm{~b}(\mathrm{NaPi}-2 \mathrm{~b})$ inhibitor ASP3325 did not reduce serum phosphorus concentrations in patients with ESRD [102]. The novel inhibitor EOS789, which interacts with several sodiumdependent phosphate transporters, decreased serum phosphorus concentrations in animal models [103] but results of a phase 1 clinical study of EOS789 in patients with CKD and hyperphosphatemia have not yet been published. Nicotinamide reduced phosphate concentrations in patients undergoing dialysis [104, 105], but a large proportion of study participants discontinued treatment due to adverse events [104]. Novel therapies targeting the paracellular pathway are logical, given a growing evidence base that the dominant mechanism of intestinal phosphate absorption is the paracellular pathway $[23,53$, 106]. One such therapy is tenapanor, an investigational first-in-class nonbinder phosphate absorption inhibitor that targets the primary absorption pathway and provides a novel approach to treating hyperphosphatemia [106]. Tenapanor has a unique mechanism of action that blocks paracellular absorption of phosphate in the GI tract by local inhibition of the sodium/hydrogen exchanger isoform 3 (NHE3) [106]. NHE3 inhibition directly reduces sodium absorption, leading to modest intracellular proton retention [106, 107]. This induces a conformational change in tight junction proteins, directly reducing permeability specific to phosphate through the paracellular pathway [106]. By blocking the primary pathway for phosphate absorption, tenapanor acts directly, efficiently, and comprehensively to reduce serum phosphate concentrations. Tenapanor effectively reduced phosphate levels in multiple clinical trials and is under FDA review as a hyperphosphatemia therapy [108-110].

To reflect the latest understandings of phosphate absorption, clinicians should consider implementing new hyperphosphatemia treatment paradigms to better achieve phosphate levels $<5.5 \mathrm{mg} / \mathrm{dL}$ (or closer to normal levels). One option could be to use targeted paracellular phosphate absorption blockers as an initial, foundational treatment. If needed, adjunctive binders could be added as part of a dual mechanism approach for patients with difficulty to control phosphate. In CKD, maladaptive phosphate retention is associated with and predictive of negative clinical consequences, even before a patient develops hyperphosphatemia $[54,111]$. Novel therapies may enhance phosphate elimination and improve patient outcomes [112-116].

\section{Conclusion}

Clinical guidelines recommend regular monitoring of phosphate levels to reduce the risk of CV morbidity and mortality $[10,96]$. Despite dietary phosphate restrictions, thrice-weekly dialysis, and phosphate binders use, management of hyperphosphatemia in patients with CKD on dialysis remain a clinical challenge as these approaches do not help achieve and maintain phosphate levels $<5.5 \mathrm{mg} /$ $\mathrm{dL}$ (or more normal levels) [10, 55-59, 98, 101]. Phosphate binders do not target the dominant paracellular pathway of phosphate absorption, have limited binding capacity, and bind nonspecifically [55-59]. Considering high mortality rates in patients with $\mathrm{CKD}$, particularly from CV causes, novel therapeutic innovations are necessary [4]. Given a growing evidence base that the dominant mechanism of phosphate absorption is the intestinal paracellular pathway $[23,53,106]$, new therapies are investigating ways to reduce phosphate levels by blocking absorption through the paracellular pathway.

\section{Statement of Ethics}

For this review article, no new research study was conducted that prospectively assigns human participants or groups of humans to one or more health-related interventions, and therefore, no patients were enrolled or subjected to therapies. Thus, there are no requirements for any ethical approval or informed consent. The process of developing this article complies with internationally accepted standards for research practice and reporting.

\section{Conflict of Interest Statement}

Dr. McCullough is a paid consultant for Ardelyx, Inc. Writing support provided by Xelay Acumen Group and funded by Ardelyx, Inc. Dr. McCullough has no other relevant affiliations or financial involvement with any organization or entity with a financial interest in or financial conflict with the subject matter or materials discussed in the manuscript apart from those disclosed. 


\section{Funding Sources}

As a review article, there was no prospective study with patients or research study staff and therefore no funding needed.

\section{Author Contributions}

The author was responsible for the review and screening of literature, conceptualization, writing, and revising of this review article.

\section{References}

1 Wetmore JB, Gilbertson DT, Liu J, Collins AJ. Improving outcomes in patients receiving dialysis: the peer kidney care initiative. Clin J Am Soc Nephrol. 2016;11(7):1297-304.

2 Astor BC, Coresh J, Heiss G, Pettitt D, Sarnak MJ. Kidney function and anemia as risk factors for coronary heart disease and mortality: the atherosclerosis risk in communities (ARIC) study. Am Heart J. 2006;151(2):492500.

3 Ye Y, Liu H, Chen Y, Zhang Y, Li S, Hu W, et al. Hemoglobin targets for the anemia in patients with dialysis-dependent chronic kidney disease: a meta-analysis of randomized, controlled trials. Ren Fail. 2018;40(1):671-9.

4 United States Renal Data System. 2019 annual data report: epidemiology of kidney disease in the United States. Bethesda, MD: National Institute of Diabetes and Digestive and Kidney Diseases; 2019.

5 United States Renal Data System. 2018 annual data report: Epidemiology of kidney disease in the United States. Bethesda, MD: National Institute of Diabetes and Digestive and Kidney Diseases; 2018

6 Naylor KL, Kim SJ, McArthur E, Garg AX, McCallum MK, Knoll GA. Mortality in incident maintenance dialysis patients versus incident solid organ cancer patients: a population-based cohort. Am J Kidney Dis. 2019; 73(6):765-76

7 Collins A, Weinhandl E. Chronic cardiovascular disease management in the dialysis population. Fresenius Med Care. 2019.

8 Cozzolino M, Mangano M, Stucchi A, Ciceri $\mathrm{P}$, Conte F, Galassi A. Cardiovascular disease in dialysis patients. Nephrol Dial Transplant. 2018;33(Suppl 1_3):iii28-34.

9 Said S, Hernandez GT. The link between chronic kidney disease and cardiovascular disease. J Nephropathol. 2014;3(3):99-104.

10 Kidney Disease: Improving Global Outcomes (KDIGO) CKD-MBD Update Work Group. KDIGO 2017 clinical practice guideline update for the diagnosis, evaluation, prevention, and treatment of chronic kidney disease: mineral and bone disorder (CKD-MBD). Kidney Int Suppl. 2017;7(1):1-59.

11 Lunyera J, Scialla JJ. Update on chronic kidney disease mineral and bone disorder in cardiovascular disease. Semin Nephrol. 2018; 38(6):542-58

12 Li J, Wang L, Han M, Xiong Y, Liao R, Li Y, et al. The role of phosphate-containing medications and low dietary phosphorus-protein ratio in reducing intestinal phosphorus load in patients with chronic kidney disease. Nutr Diabetes. 2019;9:14.
13 Mihai S, Codrici E, Popescu ID, Enciu AM, Albulescu L, Necula LG, et al. Inflammationrelated mechanisms in chronic kidney disease prediction, progression, and outcome. J Immunol Res. 2018;2018:2180373.

14 Copland M, Komenda P, Weinhandl ED, McCullough PA, Morfin JA. Intensive hemodialysis, mineral and bone disorder, and phosphate binder use. Am J Kidney Dis. 2016; 68(5s1):S24-32.

15 Shaman AM, Kowalski SR. Hyperphosphatemia management in patients with chronic kidney disease. Saudi Pharm J. 2016;24(4): 494-505.

16 Friedlaender MM, Kornberg Z, Wald H, Popovtzer MM. Renal effect of vitamin D metabolites: evidence for the essential role of the 25(OH) group. Am J Physiol. 1983;244(6): F674-8.

17 Inoue Y, Segawa H, Kaneko I, Yamanaka S, Kusano K, Kawakami E, et al. Role of the vitamin D receptor in FGF23 action on phosphate metabolism. Biochem J. 2005;390(Pt 1): 325-31.

18 Ix JH, Shlipak MG, Wassel CL, Whooley MA. Fibroblast growth factor-23 and early decrements in kidney function: the Heart and Soul Study. Nephrol Dial Transplant. 2010;25(3): 993-7.

19 Oliveira RB, Cancela AL, Graciolli FG, Dos Reis LM, Draibe SA, Cuppari L, et al. Early control of PTH and FGF23 in normophosphatemic CKD patients: a new target in CKDMBD therapy? Clin J Am Soc Nephrol. 2010; 5(2):286-91.

20 Shimada T, Hasegawa H, Yamazaki Y, Muto T, Hino R, Takeuchi Y, et al. FGF-23 is a potent regulator of vitamin $\mathrm{D}$ metabolism and phosphate homeostasis. J Bone Miner Res. 2004;19(3):429-35.

21 Shimada T, Kakitani M, Yamazaki Y, Hasegawa H, Takeuchi Y, Fujita T, et al. Targeted ablation of Fgf23 demonstrates an essential physiological role of FGF23 in phosphate and vitamin D metabolism. J Clin Invest. 2004; 113(4):561-8.

22 Slatopolsky E, Robson AM, Elkan I, Bricker NS. Control of phosphate excretion in uremic man. J Clin Invest. 1968;47(8):1865-74.

23 Saurette M, Alexander RT. Intestinal phosphate absorption: the paracellular pathway predominates? Exp Biol Med. 2019;244(8): 646-54.

24 Moore LW, Nolte JV, Gaber AO, Suki WN. Association of dietary phosphate and serum phosphorus concentration by levels of kidney function. Am J Clin Nutr. 2015;102(2):44453.
25 Estimated Glomerular Filtration Rate (eGFR). National Kidney Foundation; 2020.

26 Lopes MB, Karaboyas A, Bieber B, Pisoni RL, Walpen S, Fukagawa M, et al. Impact of longer term phosphorus control on cardiovascular mortality in hemodialysis patients using an area under the curve approach: results from the DOPPS. Nephrol Dial Transplant. 2020.

27 Major RW, Cheng MRI, Grant RA, Shantikumar S, Xu G, Oozeerally I, et al. Cardiovascular disease risk factors in chronic kidney disease: a systematic review and meta-analysis. PLoS One. 2018;13(3):e0192895.

28 Moe SM, Chertow GM. The case against calcium-based phosphate binders. Clin J Am Soc Nephrol. 2006;1(4):697-703.

29 Tonelli M, Pannu N, Manns B. Oral phosphate binders in patients with kidney failure. N Engl J Med. 2010;362(14):1312-24.

30 Kendrick J, Kestenbaum B, Chonchol M. Phosphate and cardiovascular disease. Adv Chronic Kidney Dis. 2011;18(2):113-9.

31 Moe SM, Chen NX. Pathophysiology of vascular calcification in chronic kidney disease. Circ Res. 2004;95(6):560-7.

32 Zhang D, Bi X, Liu Y, Huang Y, Xiong J, Xu $X$, et al. High phosphate-induced calcification of vascular smooth muscle cells is associated with the TLR4/NF- $k b$ signaling pathway. Kidney Blood Press Res. 2017;42(6):1205-15.

33 Lau WL, Festing MH, Giachelli CM. Phosphate and vascular calcification: emerging role of the sodium-dependent phosphate cotransporter PiT-1. Thromb Haemost. 2010; 104(3):464-70.

34 McCullough PA, Chinnaiyan KM, Agrawal V, Danielewicz E, Abela GS. Amplification of atherosclerotic calcification and Mönckeberg's sclerosis: a spectrum of the same disease process. Adv Chronic Kidney Dis. 2008; 15(4):396-412.

35 Iyemere VP, Proudfoot D, Weissberg PL, Shanahan CM. Vascular smooth muscle cell phenotypic plasticity and the regulation of vascular calcification. J Intern Med. 2006;260(3): 192-210.

36 Vickers KC, Castro-Chavez F, Morrisett JD. Lyso-phosphatidylcholine induces osteogenic gene expression and phenotype in vascular smooth muscle cells. Atherosclerosis. 2010; 211(1):122-9.

37 Crouthamel MH, Lau WL, Leaf EM, Chavkin NW, Wallingford MC, Peterson DF, et al. Sodium-dependent phosphate cotransporters and phosphate-induced calcification of vascular smooth muscle cells: redundant roles for PiT-1 and PiT-2. Arterioscler Thromb Vasc Biol. 2013;33(11):2625-32. 
38 Scialla JJ, Wolf M. Roles of phosphate and fibroblast growth factor 23 in cardiovascular disease. Nat Rev Nephrol. 2014;10(5):268-78.

39 Olauson H, Vervloet MG, Cozzolino M, Massy ZA, Ureña Torres P, Larsson TE. New insights into the FGF23-Klotho axis. Semin Nephrol. 2014;34(6):586-97.

40 Rostand SG, Drüeke TB. Parathyroid hormone, vitamin $\mathrm{D}$, and cardiovascular disease in chronic renal failure. Kidney Int. 1999; 56(2):383-92.

41 Stack AG, Bloembergen WE. A cross-sectional study of the prevalence and clinical correlates of congestive heart failure among incident US dialysis patients. Am J Kidney Dis. 2001;38(5):992-1000.

42 Scialla JJ, Xie H, Rahman M, Anderson AH, Isakova T, Ojo A, et al. Fibroblast growth factor-23 and cardiovascular events in CKD. J Am Soc Nephrol. 2014;25(2):349-60.

43 Yeung SMH, Binnenmars SH, Gant CM, Navis G, Gansevoort RT, Bakker SJL, et al. Fibroblast growth factor 23 and mortality in patients with type 2 diabetes and normal or mildly impaired kidney function. Diabetes Care. 2019;42(11):2151-3.

44 Akhabue E, Montag S, Reis JP, Pool LR, Mehta R, Yancy CW, et al. FGF23 (fibroblast growth factor-23) and incident hypertension in young and middle-aged adults: the cardia study. Hypertension. 2018;72(1):70-6.

45 Bogin E, Massry SG, Harary I. Effect of parathyroid hormone on rat heart cells. J Clin Invest. 1981;67(4):1215-27.

46 Tastan I, Schreckenberg R, Mufti S, Abdallah Y, Piper HM, Schlüter KD. Parathyroid hormone improves contractile performance of adult rat ventricular cardiomyocytes at low concentrations in a non-acute way. Cardiovasc Res. 2009;82(1):77-83.

47 Artaza JN, Norris KC. Vitamin D reduces the expression of collagen and key profibrotic factors by inducing an antifibrotic phenotype in mesenchymal multipotent cells. J Endocrinol. 2009;200(2):207-21.

48 Baksi SN, Hughes MJ. Deficiency in dietary vitamin $\mathrm{D}$, not calcium, alters noradrenergic responsiveness in rat atria in vitro. J Mol Cell Cardiol. 1986;18(7):653-6.

49 Green JJ, Robinson DA, Wilson GE, Simpson RU, Westfall MV. Calcitriol modulation of cardiac contractile performance via protein kinase C. J Mol Cell Cardiol. 2006;41(2):350-9.

50 Tanaka Y, Deluca HF. The control of 25-hydroxyvitamin D metabolism by inorganic phosphorus. Arch Biochem Biophys. 1973; 154(2):566-74.

51 Watson KE, Abrolat ML, Malone LL, Hoeg JM, Doherty T, Detrano R, et al. Active serum vitamin $\mathrm{D}$ levels are inversely correlated with coronary calcification. Circulation. 1997; 96(6): 1755-60

52 Moe SM. Disorders involving calcium, phosphorus, and magnesium. Prim Care. 2008; 35(2):215-vi.

53 Weinman EJ, Light PD, Suki WN. Gastrointestinal phosphate hytandling in CKD and its association with cardiovascular disease. Am J Kidney Dis. 2013;62(5):1006-11.

54 Dominguez Rieg JA, de la Mora Chavez S, Rieg T. Novel developments in differentiating the role of renal and intestinal sodium hydrogen exchanger 3. Am J Physiol Regul Integr Comp Physiol. 2016;311(6):R1186-r91.

$55 \mathrm{PhosLo}^{\varpi}$ gelcaps (calcium acetate). $667 \mathrm{mg}$ (prescribing information). Waltham, MA: Fresenius Medical Care North America; 2011.

56 VELPHORO $^{\circ}$. (Sucroferric oxyhydroxide) (prescribing information). Waltham, MA: Fresenius Medical Care North America; 2013.

57 FOSRENAL ${ }^{\circ}$. (Lanthanum carbonate) (prescribing information). Lexington, MA: Shire US Inc.; 2016.

58 AURYXIA $^{\circ}$. (Ferric citrate) tablets (prescribing information). Cambridge, MA: Keryx Biopharmaceuticals Inc.; 2017.

59 RENVELA*. (Sevelamer carbonate) (prescribing information). Cambridge, MA: Genzyme Corp.; 2020.

60 McGovern AP, de Lusignan S, van Vlymen J, Liyanage H, Tomson CR, Gallagher H, et al. Serum phosphate as a risk factor for cardiovascular events in people with and without chronic kidney disease: a large community based cohort study. PLoS One. 2013;8(9):e74996.

61 Foley RN. Phosphate levels and cardiovascular disease in the general population. Clin J Am Soc Nephrol. 2009;4(6):1136-9.

62 Dhingra R, Sullivan LM, Fox CS, Wang TJ, D'Agostino RB S, Gaziano JM, et al. Relations of serum phosphorus and calcium levels to the incidence of cardiovascular disease in the community. Arch Intern Med. 2007;167(9): 879-85.

63 Jia Y, Jia G. Role of intestinal $\mathrm{Na}(+) / \mathrm{H}(+)$ exchanger inhibition in the prevention of cardiovascular and kidney disease. Ann Transl Med. 2015;3(7):91.

64 Jun M, Lv J, Perkovic V, Jardine MJ. Managing cardiovascular risk in people with chronic kidney disease: a review of the evidence from randomized controlled trials. Ther $\mathrm{Adv}$ Chronic Dis. 2011;2(4):265-78.

65 Block GA, Klassen PS, Lazarus JM, Ofsthun N, Lowrie EG, Chertow GM. Mineral metabolism, mortality, and morbidity in maintenance hemodialysis. J Am Soc Nephrol. 2004; 15(8):2208-18.

66 Slinin Y, Foley RN, Collins AJ. Calcium, phosphorus, parathyroid hormone, and cardiovascular disease in hemodialysis patients: the USRDS waves 1,3 , and 4 study. J Am Soc Nephrol. 2005;16(6):1788-93.

67 Kestenbaum B, Sampson JN, Rudser KD, Patterson DJ, Seliger SL, Young B, et al. Serum phosphate levels and mortality risk among people with chronic kidney disease. J Am Soc Nephrol. 2005;16(2):520-8.

68 Block GA, Hulbert-Shearon TE, Levin NW, Port FK. Association of serum phosphorus and calcium $\mathrm{x}$ phosphate product with mortality risk in chronic hemodialysis patients: a national study. Am J Kidney Dis. 1998;31(4): 607-17.
69 Coco M, Rush H. Increased incidence of hip fractures in dialysis patients with low serum parathyroid hormone. Am J Kidney Dis. 2000;36(6):1115-21.

70 Ganesh SK, Stack AG, Levin NW, HulbertShearon T, Port FK. Association of elevated serum $\mathrm{PO}(4)$, $\mathrm{Ca} \times \mathrm{PO}(4)$ product, and parathyroid hormone with cardiac mortality risk in chronic hemodialysis patients. J Am Soc Nephrol. 2001;12(10):2131-8.

71 Saran R, Bragg-Gresham JL, Rayner HC, Goodkin DA, Keen ML, Van Dijk PC, et al. Nonadherence in hemodialysis: associations with mortality, hospitalization, and practice patterns in the DOPPS. Kidney Int. 2003; 64(1):254-62.

72 Rubel JR, Milford EL. The relationship between serum calcium and phosphate levels and cardiac valvular procedures in the hemodialysis population. Am J Kidney Dis. 2003; 41(2):411-21.

73 Port FK, Pisoni RL, Bragg-Gresham JL, Satayathum SS, Young EW, Wolfe RA, et al. DOPPS estimates of patient life years attributable to modifiable hemodialysis practices in the United States. Blood Purif. 2004;22(1): 175-80.

74 Young EW, Albert JM, Satayathum S, Goodkin DA, Pisoni RL, Akiba T, et al. Predictors and consequences of altered mineral metabolism: the dialysis outcomes and practice patterns study. Kidney Int. 2005;67(3): 1179-87.

75 Menon V, Greene T, Pereira AA, Wang X, Beck GJ, Kusek JW, et al. Relationship of phosphorus and calcium-phosphorus product with mortality in CKD. Am J Kidney Dis. 2005;46(3):455-63.

76 Rodriguez-Benot A, Martin-Malo A, AlvarezLara MA, Rodriguez M, Aljama P. Mild hyperphosphatemia and mortality in hemodialysis patients. Am J Kidney Dis. 2005;46(1): 68-77.

77 Kalantar-Zadeh K, Kuwae N, Regidor DL, Kovesdy CP, Kilpatrick RD, Shinaberger CS, et al. Survival predictability of time-varying indicators of bone disease in maintenance hemodialysis patients. Kidney Int. 2006;70(4): 771-80.

78 Melamed ML, Eustace JA, Plantinga L, Jaar BG, Fink NE, Coresh J, et al. Changes in serum calcium, phosphate, and $\mathrm{PTH}$ and the risk of death in incident dialysis patients: a longitudinal study. Kidney Int. 2006;70(2): 351-7.

79 Kimata N, Albert JM, Akiba T, Yamazaki S, Kawaguchi T, Fukuhara S, et al. Association of mineral metabolism factors with all-cause and cardiovascular mortality in hemodialysis patients: the Japan dialysis outcomes and practice patterns study. Hemodial Int. 2007; 11(3):340-8.

80 Kovesdy CP, Ahmadzadeh S, Anderson JE, Kalantar-Zadeh K. Secondary hyperparathyroidism is associated with higher mortality in men with moderate to severe chronic kidney disease. Kidney Int. 2008;73(11):1296-302. 
81 Wald R, Sarnak MJ, Tighiouart H, Cheung AK, Levey AS, Eknoyan G, et al. Disordered mineral metabolism in hemodialysis patients: an analysis of cumulative effects in the hemodialysis (HEMO) study. Am J Kidney Dis. 2008;52(3):531-40.

82 Tentori F, Blayney MJ, Albert JM, Gillespie BW, Kerr PG, Bommer J, et al. Mortality risk for dialysis patients with different levels of serum calcium, phosphorus, and PTH: the dialysis outcomes and practice patterns study (DOPPS). Am J Kidney Dis. 2008;52(3):51930.

83 Lacson E Jr, Wang W, Hakim RM, Teng M, Lazarus JM. Associates of mortality and hospitalization in hemodialysis: potentially actionable laboratory variables and vascular access. Am J Kidney Dis. 2009;53(1):79-90.

84 Smith DH, Johnson ES, Thorp ML, Petrik A, Yang X, Blough DK. Outcomes predicted by phosphorous in chronic kidney disease: a retrospective CKD-inception cohort study. Nephrol Dial Transplant. 2010;25(1):166-74.

85 Kovesdy CP, Anderson JE, Kalantar-Zadeh K. Outcomes associated with serum phosphorus level in males with non-dialysis dependent chronic kidney disease. Clin Nephrol. 2010; 73(4):268-75.

86 Tangri N, Wagner M, Griffith JL, Miskulin DC, Hodsman A, Ansell D, et al. Effect of bone mineral guideline target achievement on mortality in incident dialysis patients: an analysis of the United Kingdom renal registry. Am J Kidney Dis. 2011;57(3):415-21.

87 Floege J, Kim J, Ireland E, Chazot C, Drueke T, de Francisco A, et al. Serum iPTH, calcium and phosphate, and the risk of mortality in a European haemodialysis population. Nephrol Dial Transplant. 2011;26(6):1948-55.

88 Sakaguchi Y, Fujii N, Shoji T, Hayashi T, Rakugi $\mathrm{H}$, Iseki K, et al. Magnesium modifies the cardiovascular mortality risk associated with hyperphosphatemia in patients undergoing hemodialysis: a cohort study. PLoS One. 2014;9(12):e116273.

89 Fernández-Martín JL, Martínez-Camblor P, Dionisi MP, Floege J, Ketteler M, London G, et al. Improvement of mineral and bone metabolism markers is associated with better survival in haemodialysis patients: the COSMOS study. Nephrol Dial Transplant. 2015; 30(9):1542-51.

90 Garagarza C, Valente A, Caetano C, Oliveira T, Ponce P, Silva AP. Hypophosphatemia: nutritional status, body composition, and mortality in hemodialysis patients. Int Urol Nephrol. 2017;49(7):1243-50.

91 McCullough PA, Sandberg KR, Dumler F, Yanez JE. Determinants of coronary vascular calcification in patients with chronic kidney disease and end-stage renal disease: a systematic review. J Nephrol. 2004;17(2):205-15.
92 Shang D, Xie Q, Ge X, Yan H, Tian J, Kuang $\mathrm{D}$, et al. Hyperphosphatemia as an independent risk factor for coronary artery calcification progression in peritoneal dialysis patients. BMC Nephrol. 2015;16(1):107.

93 Qunibi WY. Consequences of hyperphosphatemia in patients with end-stage renal disease (ESRD). Kidney Int Suppl. 2004(90): S8-s12.

94 Goodman WG, Goldin J, Kuizon BD, Yoon C, Gales B, Sider D, et al. Coronary-artery calcification in young adults with end-stage renal disease who are undergoing dialysis. $\mathrm{N}$ Engl J Med. 2000;342(20):1478-83.

95 Ketteler M. Phosphate metabolism in CKD stages 3-5: dietary and pharmacological control. Int J Nephrol. 2011;2011:970245.

96 National Kidney Foundation. K/DOQI clinical practice guidelines for bone metabolism and disease in chronic kidney disease. Am J Kidney Dis. 2003;42(4 Suppl 3):S1-201.

97 Barreto FC, Barreto DV, Massy ZA, Drüeke TB. Strategies for phosphate control in patients with CKD. Kidney Int Rep. 2019;4(8): 1043-56.

98 Suki WN, Moore LW. Phosphorus regulation in chronic kidney disease. Methodist Debakey Cardiovasc J. 2016;12(4 Suppl 1): 6-9.

99 RealWorld dynamix. Dialysis US: Spherix Global Insights; 2019. (Available from: https: //www.spherixglobalinsights.com/reports/nephrology-reports/dialysis-us/).

100 Fissell RB, Karaboyas A, Bieber BA, Sen A, Li Y, Lopes AA, et al. Phosphate binder pill burden, patient-reported non-adherence, and mineral bone disorder markers: Findings from the DOPPS. Hemodial Int. 2016; 20(1):38-49.

101 Serum phosphorus (most recent), categories: Dialysis Outcomes and Practice Patterns Study (DOPPS); 2020. Available from: https: //www.dopps.org/dpm/DPMSlideBrowser.aspx?type $=$ Topic\&id $=11$.

102 Larsson TE, Kameoka C, Nakajo I, Taniuchi Y, Yoshida S, Akizawa T, et al. NPT-IIb inhibition does not improve hyperphosphatemia in CKD. Kidney Int Rep. 2018;3(1):7380.

103 Tsuboi Y, Ohtomo S, Ichida Y, Hagita H, Ozawa K, Iida M, et al. EOS789, a novel panphosphate transporter inhibitor, is effective for the treatment of chronic kidney diseasemineral bone disorder. Kidney Int. 2020; 98(2):343-54.

104 Lenglet A, Liabeuf S, Esper NE, Brisset S, Mansour J, Lemaire-Hurtel AS, et al. Efficacy and safety of nicotinamide in haemodialysis patients: the NICOREN study. Nephrol Dial Transplant. 2017;32(9):1597.
105 Takahashi Y, Tanaka A, Nakamura T, Fukuwatari T, Shibata K, Shimada N, et al. Nicotinamide suppresses hyperphosphatemia in hemodialysis patients. Kidney Int. 2004; 65(3):1099-104.

106 King AJ, Siegel M, He Y, Nie B, Wang J, KooMcCoy S, et al. Inhibition of sodium/hydrogen exchanger 3 in the gastrointestinal tract by tenapanor reduces paracellular phosphate permeability. Sci Transl Med. 2018; 10(456):eaam6474.

107 Linz D, Wirth K, Linz W, Heuer HO, Frick W, Hofmeister A, et al. Antihypertensive and laxative effects by pharmacological inhibition of sodium-proton-exchanger subtype 3 -mediated sodium absorption in the gut. Hypertension. 2012;60(6):1560-7.

108 Chertow GM, Yang Y, Rosenbaum DP. Long-term safety and efficacy of tenapanor for the control of serum phosphorus in patients with chronic kidney disease on dialysis. J. Am. Soc. Nephrol. 2020.

109 Block GA, Rosenbaum DP, Yan A, Chertow GM. Efficacy and safety of tenapanor in patients with hyperphosphatemia receiving maintenance hemodialysis: a randomized phase 3 trial. J Am Soc Nephrol. 2019;30(4): 641-52.

110 Rosenbaum DP, Yan A, Jacobs JW. Pharmacodynamics, safety, and tolerability of the NHE3 inhibitor tenapanor: two trials in healthy volunteers. Clin Drug Investig. 2018; 38(4):341-51.

111 Ritter CS, Slatopolsky E. Phosphate toxicity in CKD: the killer among us. Clin J Am Soc Nephrol. 2016;11(6):1088-100.

112 Davis GR, Zerwekh JE, Parker TF, Krejs GJ, Pak CY, Fordtran JS. Absorption of phosphate in the jejunum of patients with chronic renal failure before and after correction of vitamin D deficiency. Gastroenterology. 1983;85(4):908-16.

113 Lee DB, Walling MW, Corry DB. Phosphate transport across rat jejunum: influence of sodium, $\mathrm{pH}$, and 1,25-dihydroxyvitamin D3. Am J Physiol. 1986;251(1 Pt 1):G90-5.

114 Pentafragka C, Symillides M, McAllister M, Dressman J, Vertzoni M, Reppas C. The impact of food intake on the luminal environment and performance of oral drug products with a view to in vitro and in silico simulations: a PEARRL review. J Pharm Pharmacol. 2019;71(4):557-80.

115 Hutchison AJ, Smith CP, Brenchley PE. Pharmacology, efficacy and safety of oral phosphate binders. Nat Rev Nephrol. 2011; 7(10):578-89.

116 Hernando N, Gagnon K, Lederer E. Phosphate transport in epithelial and nonepithelial tissue. Physiol Rev. 2021;101(1):1-35. 